IvBSIR 88-3093

DEVELOPMENT OF STANDARD MEASUREMENT TECHNIQUES AND STANDARD REFERENCE MATERIALS FOR HEAT CAPACITY AND HEAT OF VAPORIZATION OF JET FUELS

Jane E. Callanan

National Bureau of Standards U.S. Department of Commerce Boulder, Colorado 80303-3328

August 1988

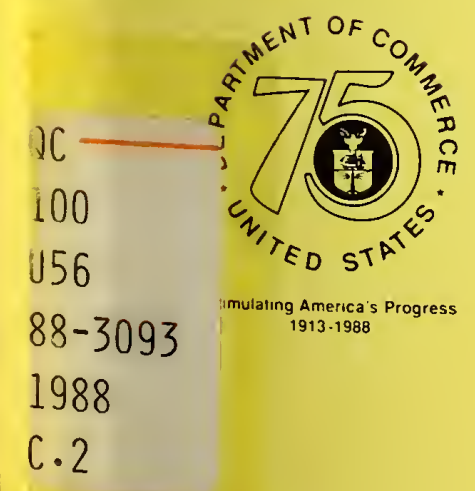





\section{DEVELOPMENT OF STANDARD MEASUREMENT TECHNIQUES AND STANDARD REFERENCE MATERIALS FOR HEAT CAPACITY AND HEAT OF VAPORIZATION OF JET FUELS}

Jane E. Callanan

Chemical Engineering Science Division

Center for Chemical Engineering

National Engineering Laboratory

National Bureau of Standards

Boulder, Colorado 80303-3328

August 1988

Prepared for

Aero Propulsion Laboratory

Air Force Wright Aeronautical Laboratories

Wright-Patterson AFB, Ohio 45433-6563

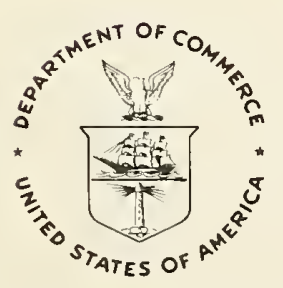

U.S. DEPARTMENT OF COMMERCE, C. William Verity, Secretary NATIONAL BUREAU OF STANDARDS, Ernest Ambler, Director 



\section{CONTENTS}

LIST OF TABLES . . . . . . . . . . . . . . . . . . . . . . . . . . . . . iv

LIST OF FIGURES . . . . . . . . . . . . . . . . . . . . . . . . . . . . iv

EXECUTIVE SUMMARY . . . . . . . . . . . . . . . . . . . . . . . . v

ABSTRACT . . . . . . . . . . . . . . . . . . . . . . . vii

INTRODUCTION . . . . . . . . . . . . . . . . . . . . . . . . . 1

APPROACH - HEAT CAPACITY . . . . . . . . . . . . . . . . . . . . 2

General . . . . . . . . . . . . . . . . . . . . 2

Use of standards . . . . . . . . . . . . . . . . . . . . . . 2

Heat capacity reference materials . . . . . . . . . . . . . . . . . 2

Measurement procedures . . . . . . . . . . . . . . . . . . 3

Corrections and data reduction . . . . . . . . . . . . . . . . . 4

RESULTS - HEAT CAPACITY . . . . . . . . . . . . . . . . . . 4

Pure materials . . . . . . . . . . . . . . . . . . . . . . . . 4

Jet fuels . . . . . . . . . . . . . . . . . . . . 5
$\mathrm{JP}-4$
(5); JP - 7
(5); JP - 8x
(5); All fuels
(6)

TECHNICAL DIFFICULTIES - HEAT CAPACITY . . . . . . . . . . . . . . 6

APPROACH - ENTHALPY OF VAPORIZATION . . . . . . . . . . . . . . . . 20

RESULTS - ENTHALPY OF VAPORIZATION . . . . . . . . . . . . . 22

TECHNICAL DIFFICULTIES - ENTHALPY OF VAPORIZATION . . . . . . . . . . . 24

ACKNOWLEDGEMENTS . . . . . . . . . . . . . . . . . . . . . . . . 24

REFERENCES . . . . . . . . . . . . . . . . . . . . . 25 


\section{LIST OF TABLES}

Table

1. Coefficients of fitted heat capacity equation $\quad 10$

2. Heat capacity of jet fuels 10

3. Enthalpy of vaporization for pure materials 23

4. Comparison with literature data - enthalpy of vaporization 23

\section{LIST OF FIGURES}

Figure

1. Deviation plot showing fit of heptane literature data. 7

2. Deviation plot for duplicate measurements on diphenyl ether, 8 $310-355 \mathrm{~K}$.

3. Plot of replicate measurements on diphenyl ether, 225-355 K. 9

4. Specific heat of a single specimen of JP-4 showing transition 11 at $320 \mathrm{~K}$.

5. Fitted specific heat of JP-4. 12

6. Deviation plot for replicate measurements on JP-4. 13

7. Specific heat of a single specimen of JP-7 showing initial 14 transition.

8. Fitted specific heat of JP-7. 15

9. Deviation plot for replicate measurements on JP-7. 16

10. Specific heat of a single specimen of JP-8x showing transition 17 from 220-240 K.

11. Fitted specific heat of JP-8x. 18

12. Deviation plot for replicate measurements on JP-8x. 19

13. Plot for determination of heat of vaporization. Curve a, 21 vaporization curve; curve b, mass loss curve. 


\section{EXECUTIVE SUMMARY}

\section{$\underline{\text { GOALS }}$}

- Develop measurement techniques for the heat capacity of jet fuels from 220 to $360 \mathrm{~K}$ ( -53 to $\left.87^{\circ} \mathrm{C}\right)$.

- Develop measurement procedures for heat of vaporization using a commercial calorimeter.

- Identify a suitable reference liquid for heat capacity to replace the customary sapphire standard.

\section{$\underline{\text { APPROACH }}$}

- Identify suitable reference liquids through a literature search and obtain them in requisite purity.

- Apply measurement procedures developed in this laboratory to these reference materials to permit 1 . their evaluation and 2. comparison with results with a sapphire standard.

- Measure the heat capacity of JP-4, JP-7, and JP-8x.

- Apply one of several possible methods for determining heat of vaporization with commercial calorimetric equipment.

- Measure the heat of vaporization of pure materials with varying boiling points to permit evaluation of the suitability of the procedures, their accuracy and precision.

- Make preliminary measurements of the heat of vaporization of fuels.

\section{FINDINGS}

- Heptane is a suitable reference liquid for heat capacity measurements from 220 to $360 \mathrm{~K}\left(-53\right.$ to $87^{\circ} \mathrm{C}$ ).

- The heat capacity of a second reference fluid (diphenyl ether) was measured over a limited temperature range with an accuracy of better than 1.4 percent and a precision of \pm 0.4 percent.

- The heat capacities of three jet fuels were determined with the precision indicated (fuel, precision). The data are given in tabular form and by representative equations.

$$
\begin{aligned}
& \mathrm{JP}-4, \pm 28 \\
& \mathrm{JP}-7, \pm 1.58 \\
& \mathrm{JP}-8 \mathrm{x}, \pm 28
\end{aligned}
$$

- The heats of vaporization of cyclohexane, cis-decalin and heptane were measured with a precision of better than +1.0 percent.

- Agreement with literature values for heats of vaporization was satisfactory, particularly in view of the differences between 1. our measurement temperature and the listed boiling point and 2. measuring techniques (calorimetry versus vapor pressure).

\section{RECOMMENDATIONS}

- Extend measurements to higher temperature ranges ( 340 to $520 \mathrm{~K}, 67$ to 247 ${ }^{\circ} \mathrm{C}$; 500 to $680 \mathrm{~K}, 227$ to $407{ }^{\circ} \mathrm{C}$ ).

- Identify a second reference liquid in order to extend this work to highor temperatures; heptane is useful only to about $450 \mathrm{~K}\left(177^{\circ} \mathrm{C}\right)$. 
Determine the best method of applying the correction for vaporization within sealed cells. This correction must be applied at higher temperatures.

- Measure the heats of vaporization of mixtures of pure materials, which have known heats of vaporization; this work must precede further measurements of the heat of vaporization of the fuels to allow for needed modifications of procedures.

o Measure the heat of vaporization of jet fuels with the newly-developed procedures.

- Investigate the accuracy and precision associated with summation of heats of vaporization over broad temperature regions or to the application of scanning methods.

- Evaluate techniques on a broader range of fuels, including endothermic fuels.

- Prepare for one of the ultimate goals of the work: the introduction of the measurement techniques to the American Society of Testing and Materials (ASTM) and the development of a standard reference material for measurements on jet fuels to be distributed by the National Bureau of Standards . 


\begin{abstract}
Development of standard measurement techniques and standard reference materials for heat capacity and heat of vaporization of jet fuels
\end{abstract}

Jane E. Callanan

Chemical Engineering Science Division

National Bureau of Standards

Boulder, Colorado

Procedures developed in the NBS-Boulder Laboratory for heat capacity

measurements of solids have been adapted successfully for the determination of liquid heat capacities. Heptane was used as a standard in the measurement of the heat capacity of three jet fuels, JP-4, JP-7, and JP-8x, from 220 to $360 \mathrm{~K}$. Transitions were observed in these fuels as follows (fuel, temperature): JP-4, $320 \mathrm{~K}$; JP-7, 220-230 K; JP-8x, 220-240 K. Combined thermogravimetric and scanning calorimetric techniques were used successfully to measure heats of vaporization of cyclohexane, cis-decalin, and heptane. The precision of these measurements was better than 0.9 percent; agreement with literature values was satisfactory in view of small differences between the measuring temperature and the literature values for the boiling points.

Key words: differential scanning calorimetry; heat capacity; heat of vaporization; jet fuels; organic liquids; thermogravimetry. 



\section{INTRODUCTION}

The two major concerns in the work reported here were the development of reliable measurement techniques, which could be applied to jet fuels, both for heat capacity and for heat of vaporization. These techniques were to be developed for commercially available calorimeters, most probably differential scanning calorimeters.

For the first portion of the work, the temperature range of the heat capacity measurements was 220 to $360 \mathrm{~K}$ ( -53 to $87^{\circ} \mathrm{C}$ ); heats of vaporization were to be determined at 300 and $350 \mathrm{~K}\left(27\right.$ and $77^{\circ} \mathrm{C}$ ). It was hoped that a suitable liquid reference material could be found and substituted for the sapphire reference, which is so commonly used for heat capacity measurements. A liquid reference would exhibit behavior more like the jet fuels than would a solid reference material.

The enthalpy of vaporization is by definition the enthalpy required to vaporize a quantity of liquid without change in temperature. This quantity may be determined at the normal boiling point or at temperatures removed from it.

Enthalpies of vaporization are often determined from vapor pressure measurements through use of the Le Chatelier principle and the ClausiusClapeyron equation. This procedure involves the assumption that the enthalpy of vaporization is independent of temperature. This assumption is valid only over narrow temperature ranges.

Classical calorimetric methods for the determination of the enthalpy of vaporization are discussed in detail by Partington [1]. These methods may be difficult to apply or involve complex apparatus. More recently, several techniques involving commercial calorimeters have been developed. [2-б́]

The original plan for this portion of the study involved use of 1 . Hsu's procedures and equipment (a modified power-compensated scanning calorimeter (4]) and 2. a commercial Calvet calorimeter. In the course of the work, however, Pratt and Whitney requested that we delay measurements on the first system and proceed directly to the Calvet calorimeter work.

A long range goal of the program is establishment of a standard measurement method and a standard reference material that 1) would permit comparisons among fuels, 2) might be submitted to the American Society for Testing and Materials for approval, and 3) would facilitate the certification of a standard reference liquid, distributed by the office of Standard Reference Materials of the National Bureau of Standards, to be used by industry. 


\section{APPROACH - HEAT CAPACITY}

\section{Genera1}

General procedures developed previously in our laboratory were applied to the heat capacity measurements of the liquids with both sapphire and a potential reference liquid as standards. The procedures used in our laboratory, described briefly here, are described more fully elsewhere.

Measurements in our laboratory are made with a commercially available powercompensated scanning calorimeter, which is adjusted for optimal performance before the beginning of each new study. These adjustments vary not only with the type of instrument but also with the individual instrument; the frequency with which adjustments and calibration are required depends on the behavior characteristics of the individual instrument being used and the accuracy required for the results. Some general guidelines are provided.

Before beginning a new study, the general condition of the instrument should be checked and any defects remedied. Attention should be paid to dirty sample holders or gas lines, poor fit of moving parts, worn o-rings, deformed or darkened specimen cells for reference, empty, and standards, and gas flow balance. Following these gross adjustments, the calorimeter baseline and temperature calibration, over the range of temperature to be used for the measurements, are to be checked and adjusted according to the manufacturer's instructions. It is essential that these adjustments be made at the scan rate and with the gas flow that will be used for the measurements.

When these adjustments are satisfactory, three measurements of the heat capacity of a standard substance are made over the temperature range and under the conditions to be used in the study. The first and third of these are used as standards and provide correction factors for the second, which is treated as a sample. Thus, the accuracy associated with the measuring conditions can be assessed.

\section{Use of standards}

Standards are essential to heat capacity measurements made with a scanning calorimeter since these instruments are not absolute measuring instruments; true values can be obtained only by use of calibration standards. Even instruments with an electrical calibration capability (Joule calibration) require verification of the correctness of the values determined for the standard. However, this latter group of instruments may require less frequent use of standards than instruments lacking this capability.

\section{Heat capacity reference materials}

a-alumina oxide (sapphire) is the most widely used reference material for heat capacity in the temperature range used in this study because of its stability and the availability of excellent reference data. [8] However, since measurements made with scanning calorimeters are affected by the nature 
of the sample, particularly its thermal conductivity, it was desirable to investigate the use of a reference liquid to be used in fuel studies. Also, a liquid reference would show vaporization properties more like those of the fuels than sapphire. The liquid selected must be available in pure form and have reliable reference data. Ideally, the reference data would refer to the actual standard substance used.

Standard reference heptane was developed in 1952 under the auspices of The Calorimetry Conference; reference values are available for this material.[9] A limited quantity was obtained and used as a reference in this work, in addition to sapphire.

A sample of pure diphenyl ether, distributed by NBS as a fusion standard, was used as a second reference liquid to allow for comparison of results with the sapphire and heptane standards. Accurate heat capacity measurements exist for diphenyl ether, though they were not made on the actual material used. [9]

\section{Measurement procedures}

Standard reference mercury (SRM 2225 NBS) [10] and certified naphthalene (CRM 16-03 NPL) [11] were used for the temperature calibration of the calorimeter.

The specimen cells found to be satisfactory for this work were large volume (c. $45 \mu 1$ ) stainless steel cells sealed with a Viton ${ }^{1}$ o-ring. Microliter syringes were used to inject 40 to $50 \mu \mathrm{L}$ into the cells. Specimen masses, which were determined on a balance calibrated to $0.01 \mathrm{mg}$, varied from 23.53 to $57.07 \mathrm{mg}$. The cells were reweighed after each use; measurements on cells which showed a mass loss of 0.2 percent or greater were discarded as invalid.

Measurements were made at $2.5 \mathrm{~K} \cdot \mathrm{min}^{-1}$ over the temperature range 220 to 360 $\mathrm{K}$. A constant flow of argon was maintained through the head during the measurements; a dry box enclosure over the head itself was maintained under a flow of dry nitrogen. The measurement sequence used was empty, standard, sample, standard, sample,....,standard. Sapphire and heptane were used as standards with both diphenyl ether and the fuel samples provided. Specimens were placed in the calorimeter at $360 \mathrm{~K}$; this procedure provided conditioning of the cells so that any volatile material adhering to the outer cell surface would be removed before measurements were begun.

1. Certain commercial equipment, instruments, or materials are identified in this paper in order to adequately specify the experimental procedure. Such identification does not imply recommendation or endorsement by the National Bureau of Standards. nor does it imply that the materials or equipment identified are necessarily the best available for the purpose. 


\section{Corrections and data reduction}

The data reduction procedures used in our work incorporate a pan weight correction in the initial measurement program. The data for heat capacity as a function of temperature for standards and samples are transmitted to a mainframe computer for further processing. Correction factors are calculated for the standards run before and after each sample; these are time averaged with reference to the sample run and are applied to the heat capacity determined by the instrument. Data for replicate ${ }^{2}$ runs are fitted and the fitted curve for the heat capacity is derived; the equation for this curve and deviations from it are also determined.

\section{RESULTS - HEAT CAPACITY}

\section{Pure materials}

Preliminary studies with heptane and sapphire as standards and diphenyl ether and JP-7 as test fluids showed that heptane was an excellent reference material. Diphenyl ether was a useful test liquid for this work despite the existence of a fusion transition at room temperature. The heat capacity data above and below the transition were uniform and reproducible, as was the transition. No problems were experienced in measuring the heat capacities of the JP-7.

Because of instrumental difficulties experienced in the preliminary work, the only quantitative data cited in this report are from later studies, made after these difficulties had been solved.

Evaluation of the accuracy of heptane and sapphire data under the conditions of the study showed heptane accuracy to vary from 0.7 to 1.4 percent from 220 to $360 \mathrm{~K}$. The accuracy of the sapphire data varied from 0.9 to 2.5 percent. Therefore, Calorimetry Conference heptane was used as the reference material (standard) for all data reported here.

Literature values for the heat capacity of the Calorimetry Conference heptane ${ }^{9}$ were fitted to derive an equation,

$$
\begin{aligned}
\mathrm{C}_{\text {sat }} & =0.65983238 \times 10^{1}-0.69114058 \times 10^{-1} \mathrm{~T} \\
& +0.39371944 \times 10^{-3} \mathrm{~T}^{2}-0.10822115 \times 10^{-5} \mathrm{~T}^{3} \\
& +0.15057257 \times 10^{-8} \mathrm{~T}^{4}-0.8336760 \times 10^{-12} \mathrm{~T}^{5}
\end{aligned}
$$

where $\mathrm{C}_{\text {sat }}$ is the saturated heat capacity and $\mathrm{T}$ the Kelvin temperature. This

2. In this report, the term replicate refers to multiple specimens of the sample; the term repeat, to a single specimen that is rerun after its first run. 
equation was incorporated into the correction program. The deviation plot for this fit is shown in figure 1 .

Measurements on diphenyl ether from 310 to $360 \mathrm{~K}$ with heptane as a reference liquid showed an accuracy of 0.8 to 1.4 percent and a precision of \pm 0.4 percent over the temperature range of the study. The deviation plot for diphenyl is given in figure 2. Figure 3 shows the results of four measurements on the diphenyl over the entire 220-360 $\mathrm{K}$ range.

\section{Jet fuels}

The heat capacity measurements, as depicted on the calorimeter screen, showed variations among the fuels but reproducible behavior for each fuel. Each fuel is discussed individually here, but data are tabulated for all three fuels in tables 1 and 2 .

$\mathrm{JP}-4$

The heat capacity scan depicted on the calorimeter screen always showed a narrow, sharp transition around 315 - $320 \mathrm{~K}$. The temperature of this event varied slightly from specimen to specimen. The corrected data used for fitting sometimes showed elevated values for these temperatures and sometimes did not (figure 4). Data for fitting were spaced at $5 \mathrm{~K}$ intervals; as a result, small variations in the temperature of the maximum were not observed in the corrected data. In order to derive an equation representing the heat capacity of JP-4, the data through the transition region were smoothed if necessary. The energy of this transition was $0.39 \mathrm{~J}$ $\mathrm{g}^{-1}$. The plot of the fitted heat capacities for replicate runs (figure 5) shows the fit of the data; a deviation plot for the fit is given in figure 6 . Replicate runs showed a variability of \pm 2 percent; repeat runs on a single specimen agreed within \pm 1 percent.

JP - 7

The heat capacity values for JP-7 at $225 \mathrm{~K}$ were always high. Its behavior during the equilibration period and information from Pratt and Whitney indicate that a transition has just been completed at this temperature (figure 7). Once that event is over, the heat capacity curve is uneventful. The fitted curve for JP-7, representing data from 230 to $360 \mathrm{~K}$, is given in figure 8; the deviation plot is shown in figure 9. Replicate runs varied by \pm 1.5 percent; repeat runs by \pm 2 percent.

$\mathrm{JP}-8 \mathrm{x}$

The heat capacity of JP-8x on the calorimeter monitor showed a broad, illdefined transition beginning at $220 \mathrm{~K}$. On fitting these data, a rather sharp transition is apparent from 220-240 K (figure 10). Replicate runs varied by about \pm 2 percent; repeat runs, by \pm 0.6 percent. Figures 11 and 12 show the fitted data and the deviation plot. 


\section{All fuels}

The coefficients of the equation,

$$
\mathrm{C}_{\mathrm{Sat}}=\mathrm{a}_{1}+\mathrm{a}_{2} \times \mathrm{T}+\mathrm{a}_{3} \times \mathrm{T}^{2}+\mathrm{a}_{4} \times \mathrm{T}^{3} \text {, }
$$

are given for all three fuels in table 1 . Heat capacity data for the three fuels are presented in table 2.3

\section{TECHNICAL DIFFICULTIES - HEAT CAPACITY}

The sapphire measurements from just prior to the beginning of the measurements for this contract were of satisfactory accuracy. In the course of the preliminary work, it was noted that sapphire scans had deteriorated; a check of the accuracy of the sapphire and heptane showed that instrument performance had deteriorated severely and it was necessary to install a new head and recalibrate the calorimeter.

Hermetically sealed specimen cells, which were used originally, could not be sealed reliably with the liquids in this study. The configuration of these cells is such that they are difficult to use with liquids. If any liquid makes its way to the lip of the cell, it does not seal properly. Attempts to seal the liquid in a large-volume, stainless steel, cell were successful and these cells were used for the remainder of the measurements. It was necessary to heat at $2.5 \mathrm{~K} \cdot \mathrm{min}^{-1}$, however, because of the lower thermal conductivity of the system. The accuracy and precision estimates were reevaluated using the stainless steel cells.

Some difficulty was experienced in sealing the stainless steel cells. It is essential that the sealed cell have an absolutely flat bottom surface for contact with the heater/thermometer unit. Excess pressure in sealing causes the bottom surface of the pan to become concave.

The pure material, diphenyl, showed excellent precision and accuracy in the test runs. The precision of the fuels is less good. Two factors may contribute to this behavior. First, the time required to sample and to seal the cells varied from specimen to specimen; it is believed now that some volatilization may have occurred as the cells were being sealed, even though the fluids were cold. Thus, the actual content of the cells differed slightly. Second, there were variations in the specimen volume to cell volume ratio in the specimens used. The sample placed in the cell varied from 40 to $50 \mu \mathrm{L}$. Since the amount of material was determined from its mass, the precise volume added was thought to be immaterial. In addition, the sealing process was such that there could be slight variations in the total cell volume. It is now recognized that slight differences in the ratio of specimen volume to cell volume may affect the heat capacity results. It is

3. For correct determination of the heat capacity at various temperatures, it is essential that all digits given for the coefficients of the equation be retained. 


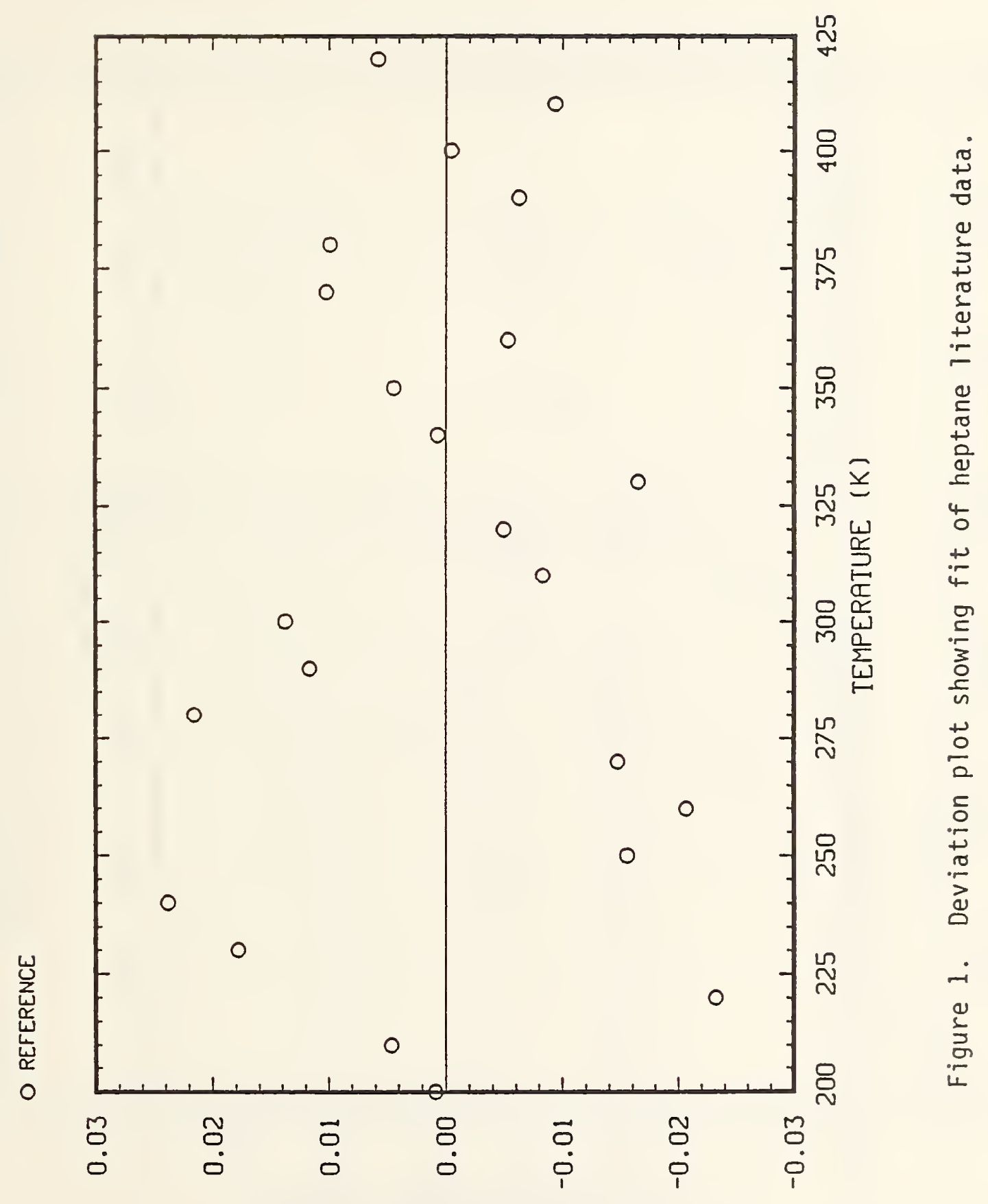

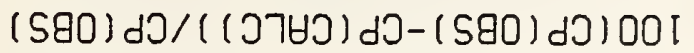




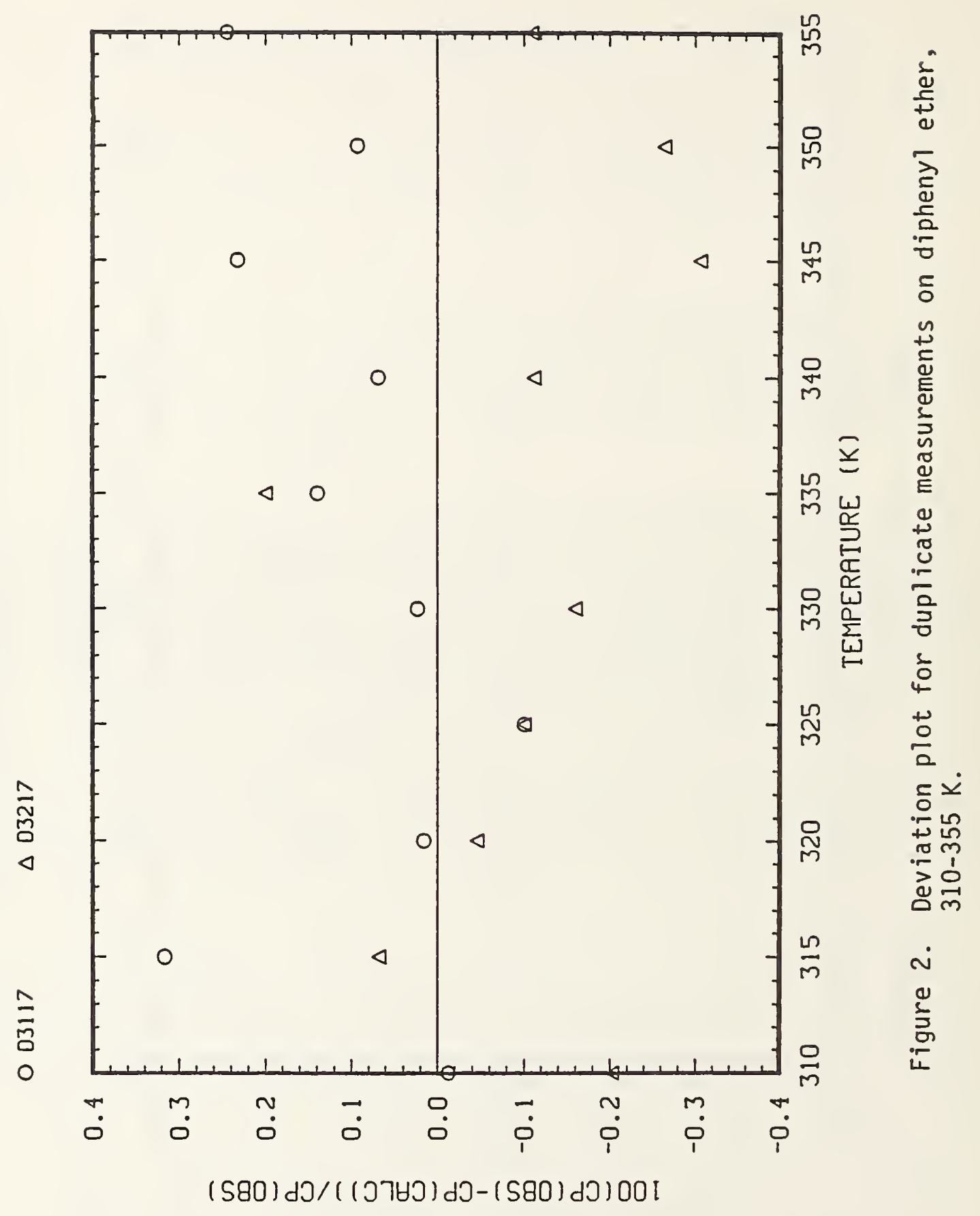




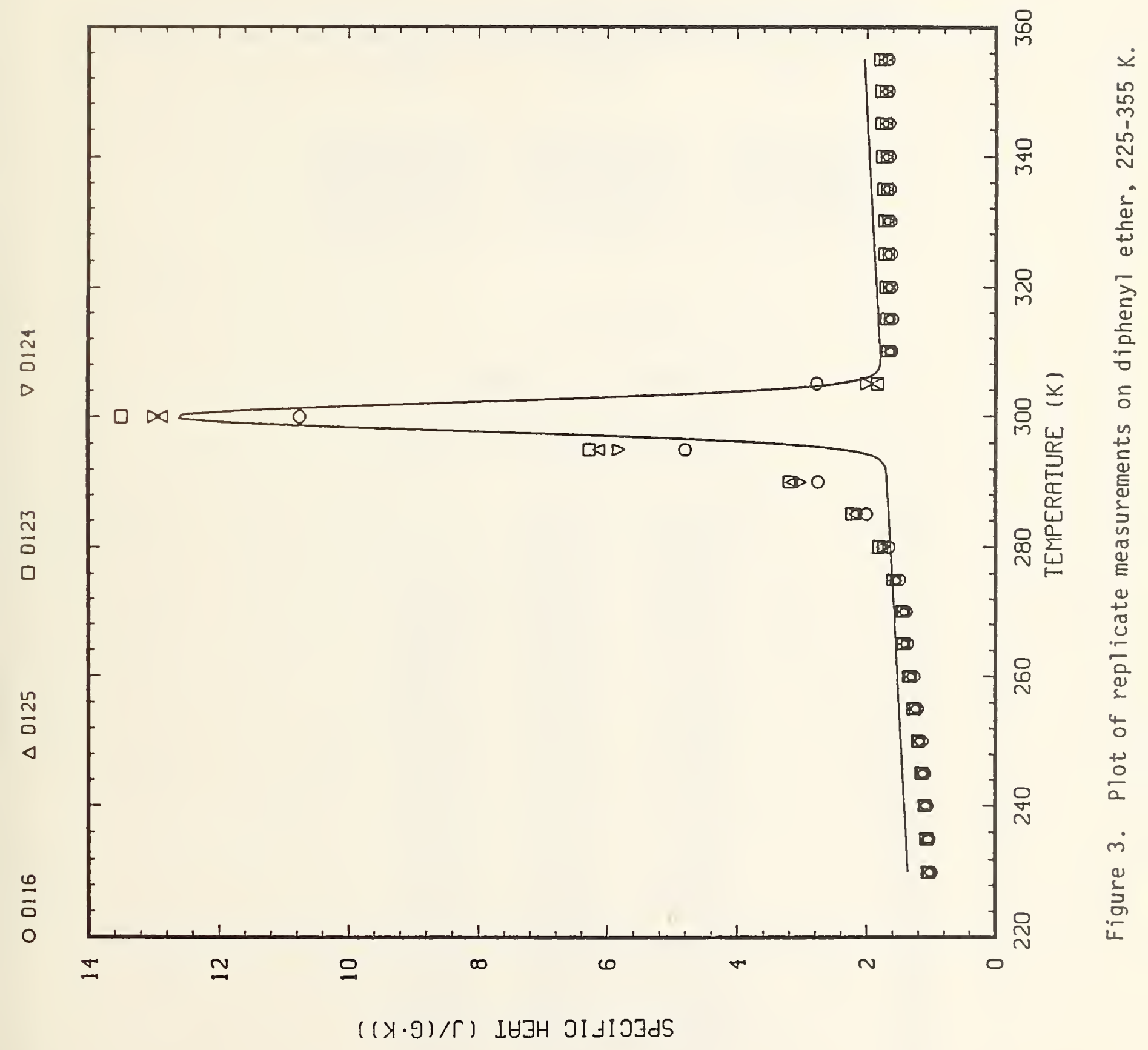


Table 1.

Coefficients of fitted heat capacity equation

$\begin{array}{llll}\text { m } & \text { JP }-4 & \text { JP }-7 & \text { JP }-8 x\end{array}$

$12.7814903 e+00 \quad 3.88956330 e+00 \quad 3.02391470 e+00$

$2-1.6220220 \mathrm{e}-02-2.85037580 \mathrm{e}-02-2.20516230 \mathrm{e}-02$

$37.1702244 \mathrm{e}-05 \quad 1.15508970 \mathrm{e}-04 \quad 9.44146410 \mathrm{e}-05$

$4-8.4395979 e-08-1.37130860 e-07-1.13743400 e-07$

Table 2 .

Heat capacity of jet fuels

$\begin{array}{lccc}\mathrm{T}(\mathrm{K}) & \begin{array}{c}\text { Heat } \\ \mathrm{JP}-4\end{array} & \mathrm{JP}-7 & \mathrm{JP}-8 \mathrm{x} \\ & & & \\ 225 & 1.801 & -.-. & \ldots \\ 230 & 1.817 & 1.776 & \ldots . . \\ 235 & 1.834 & 1.790 & -. . \\ 240 & 1.852 & 1.806 & 1.597 \\ 245 & 1.870 & 1.823 & 1.616 \\ 250 & 1.889 & 1.840 & 1.635 \\ 255 & 1.908 & 1.858 & 1.654 \\ 260 & 1.928 & 1.877 & 1.674 \\ 265 & 1.948 & 1.896 & 1.694 \\ 270 & 1.968 & 1.915 & 1.714 \\ 275 & 1.988 & 1.935 & 1.734 \\ 280 & 2.009 & 1.954 & 1.755 \\ 285 & 2.029 & 1.974 & 1.775 \\ 290 & 2.049 & 1.993 & 1.795 \\ 295 & 2.070 & 2.013 & 1.815 \\ 300 & 2.090 & 2.032 & 1.835 \\ 305 & 2.110 & 2.050 & 1.854 \\ 310 & 2.130 & 2.069 & 1.873 \\ 315 & 2.149 & 2.086 & 1.891 \\ 320 & 2.168 & 2.103 & 1.908 \\ 325 & 2.186 & 2.119 & 1.925 \\ 330 & 2.204 & 2.134 & 1.941 \\ 335 & 2.222 & 2.148 & 1.956 \\ 340 & 2.238 & 2.161 & 1.970 \\ 345 & 2.254 & 2.173 & 1.983 \\ 350 & 2.269 & 2.184 & 1.995 \\ 355 & 2.284 & 2.193 & 2.005\end{array}$

* The heat capacities given in this table represent smoothed data for all of the experimental measurements on the fuels. 


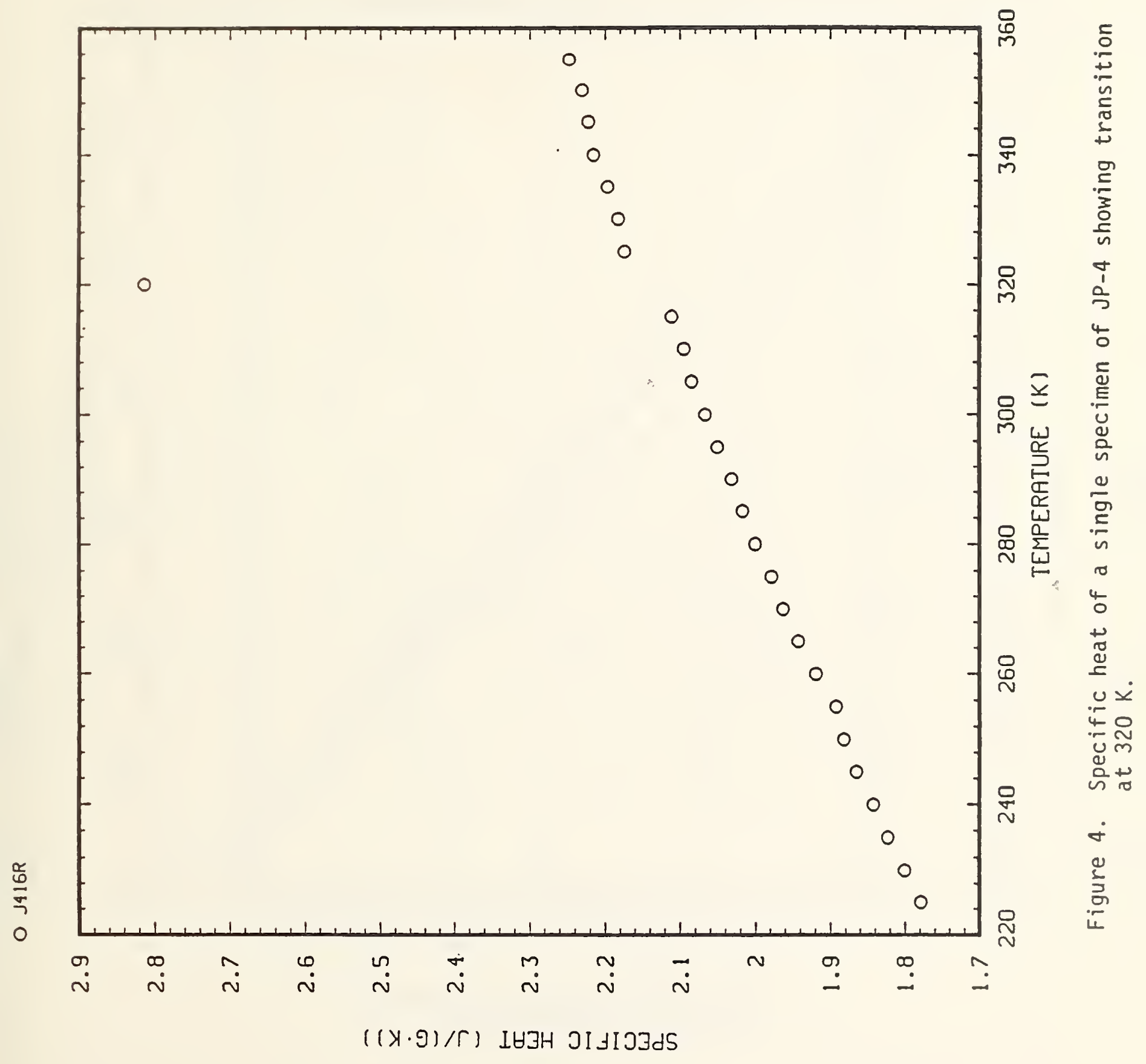




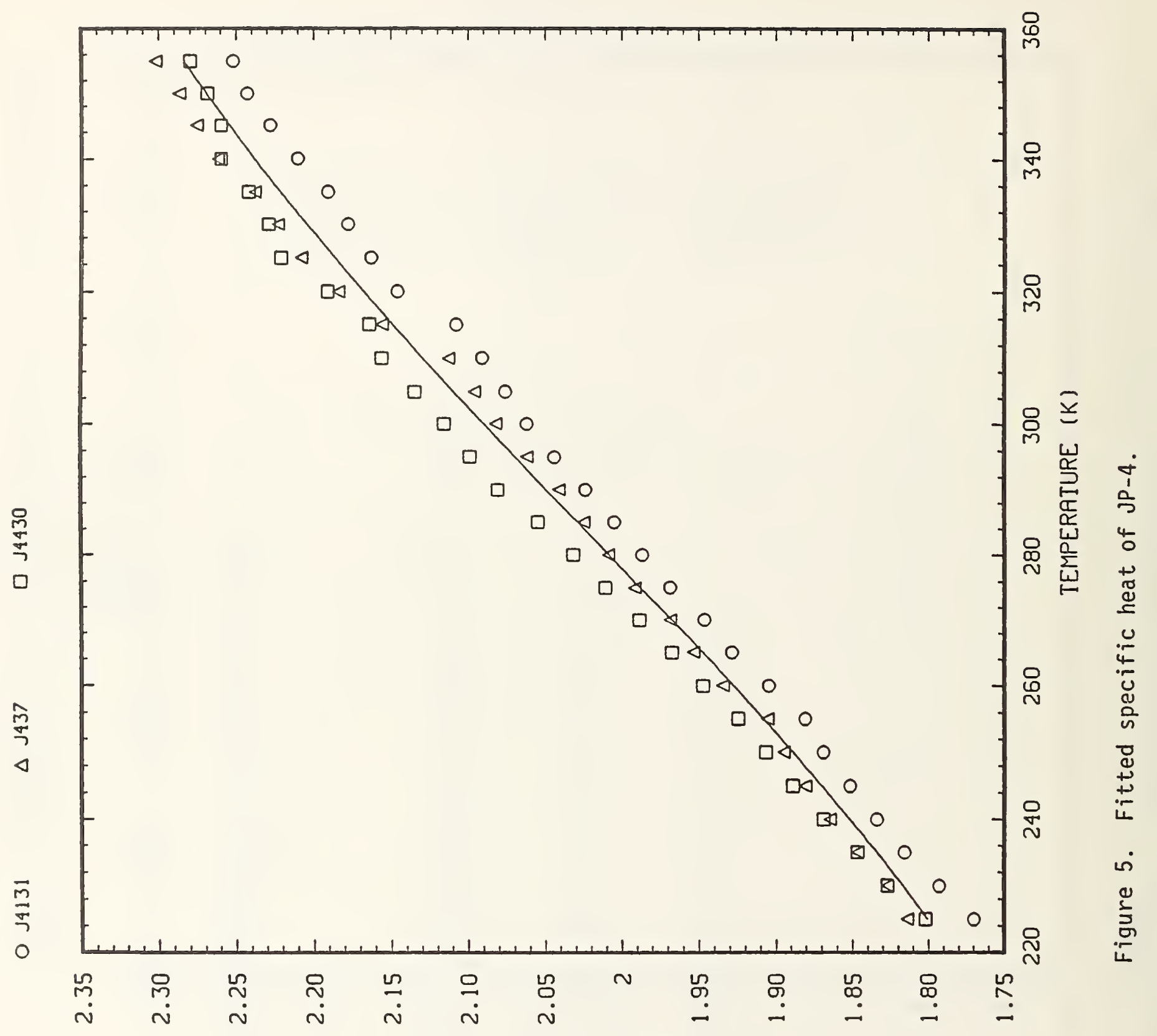

$((x \cdot 2) / C)$ IHJH JIJIJJdS 


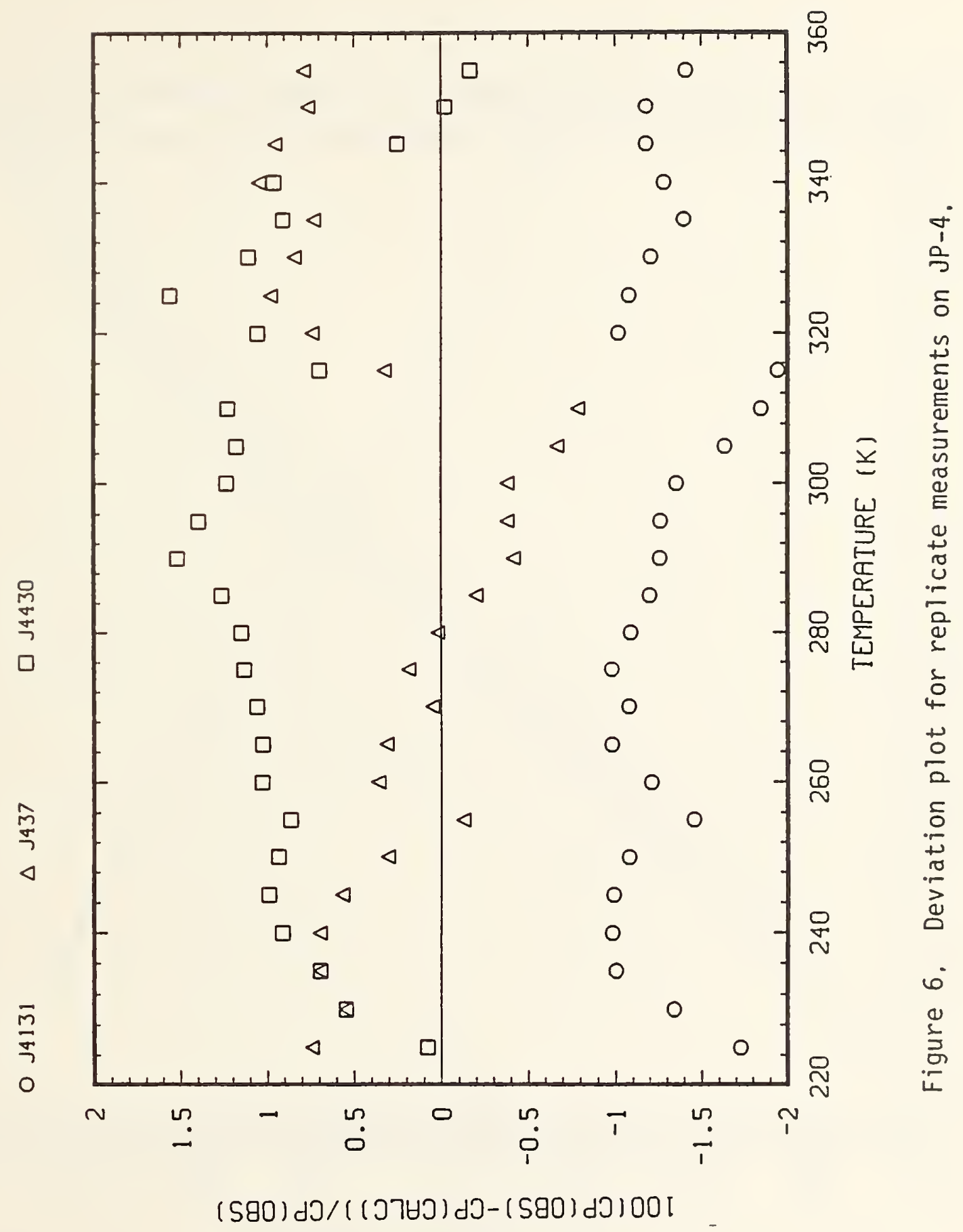




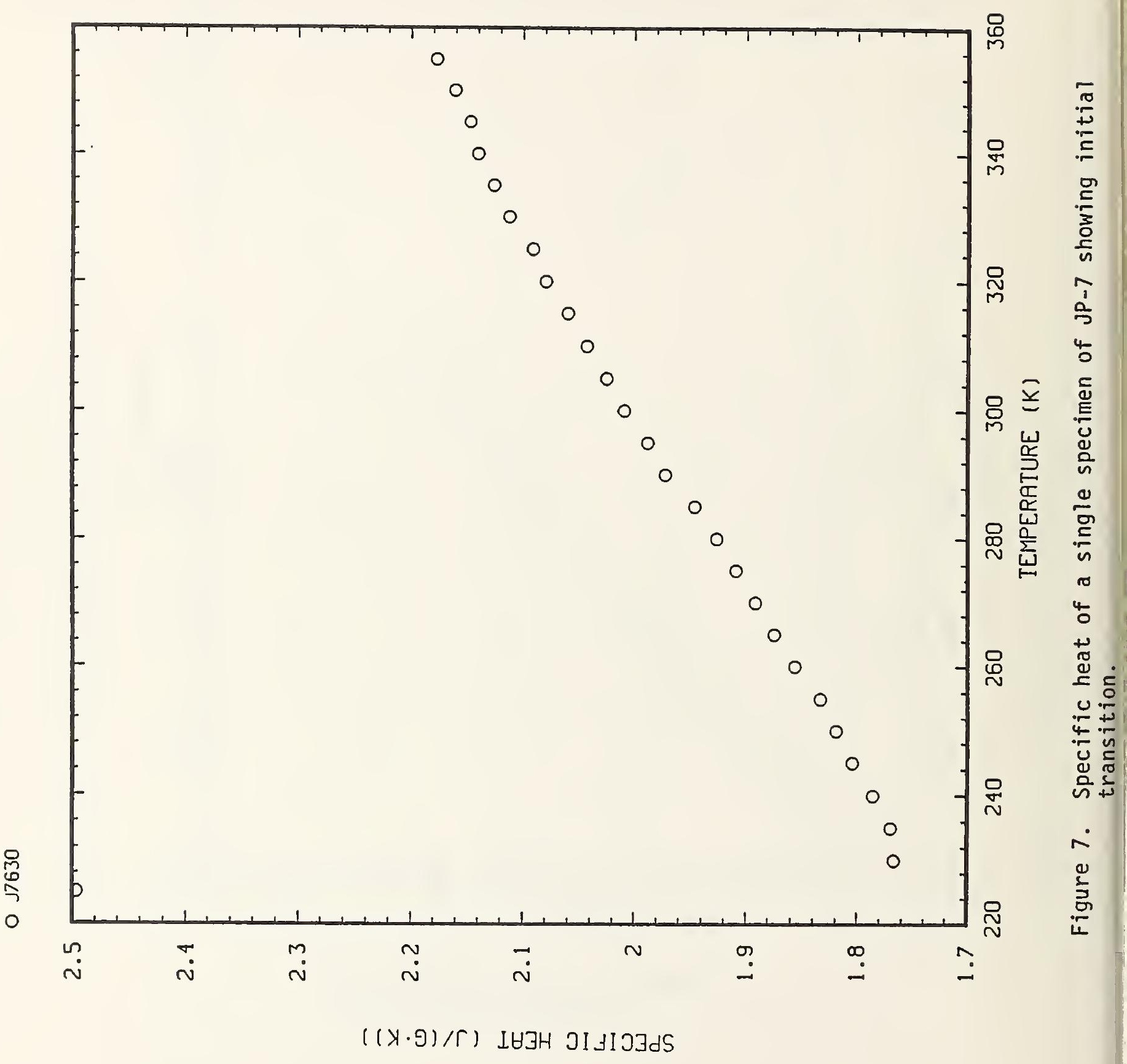




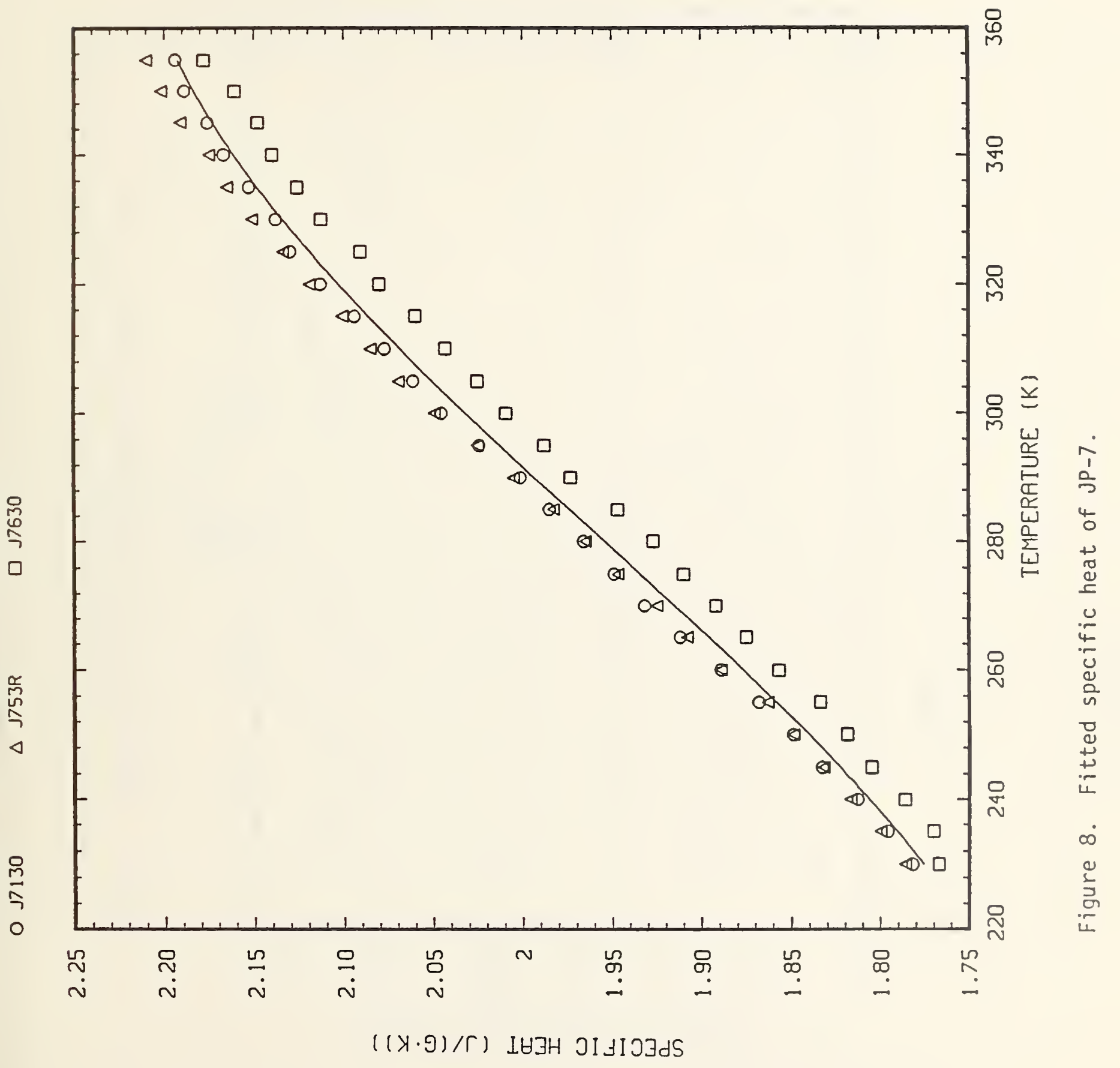




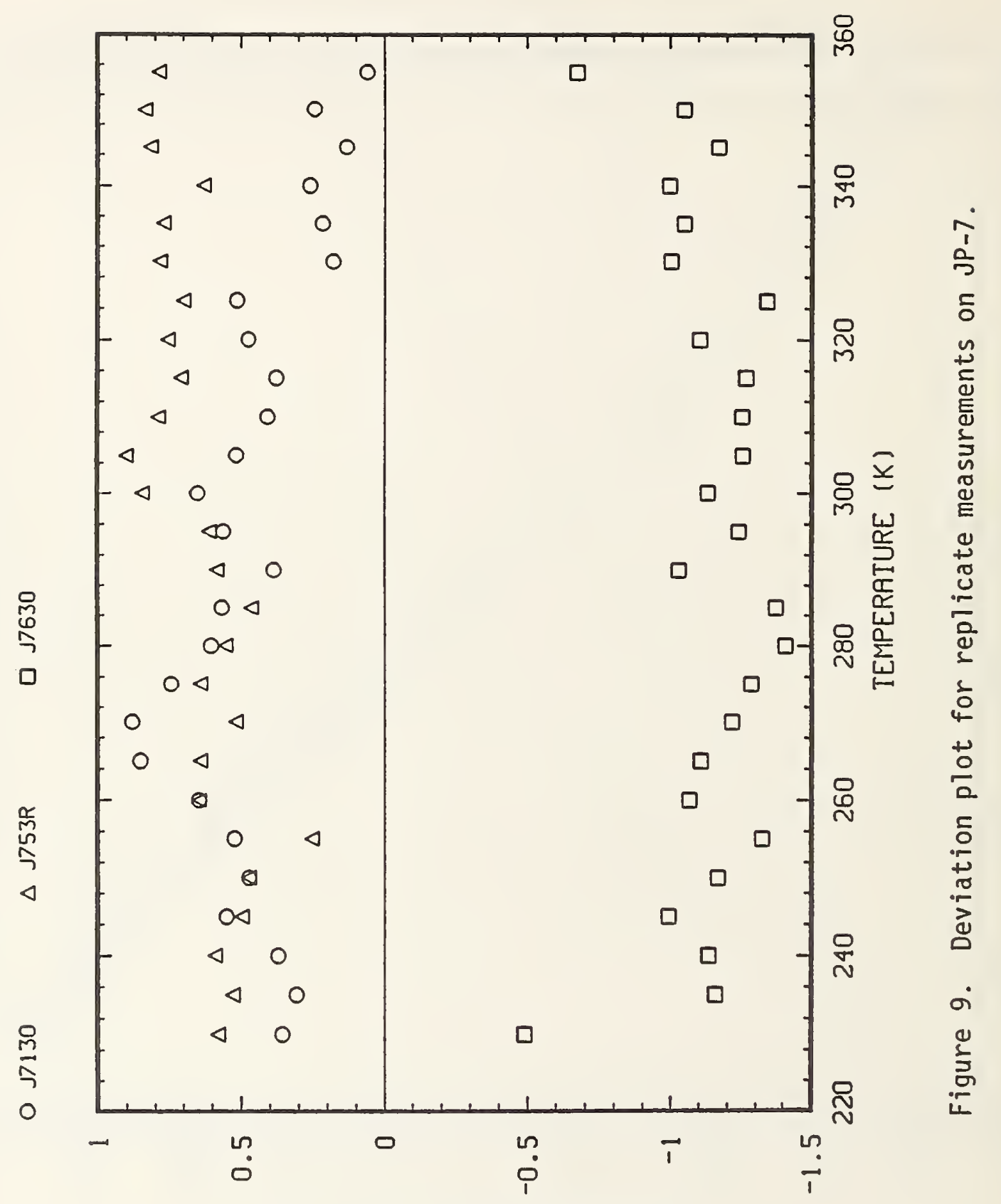

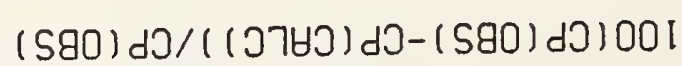




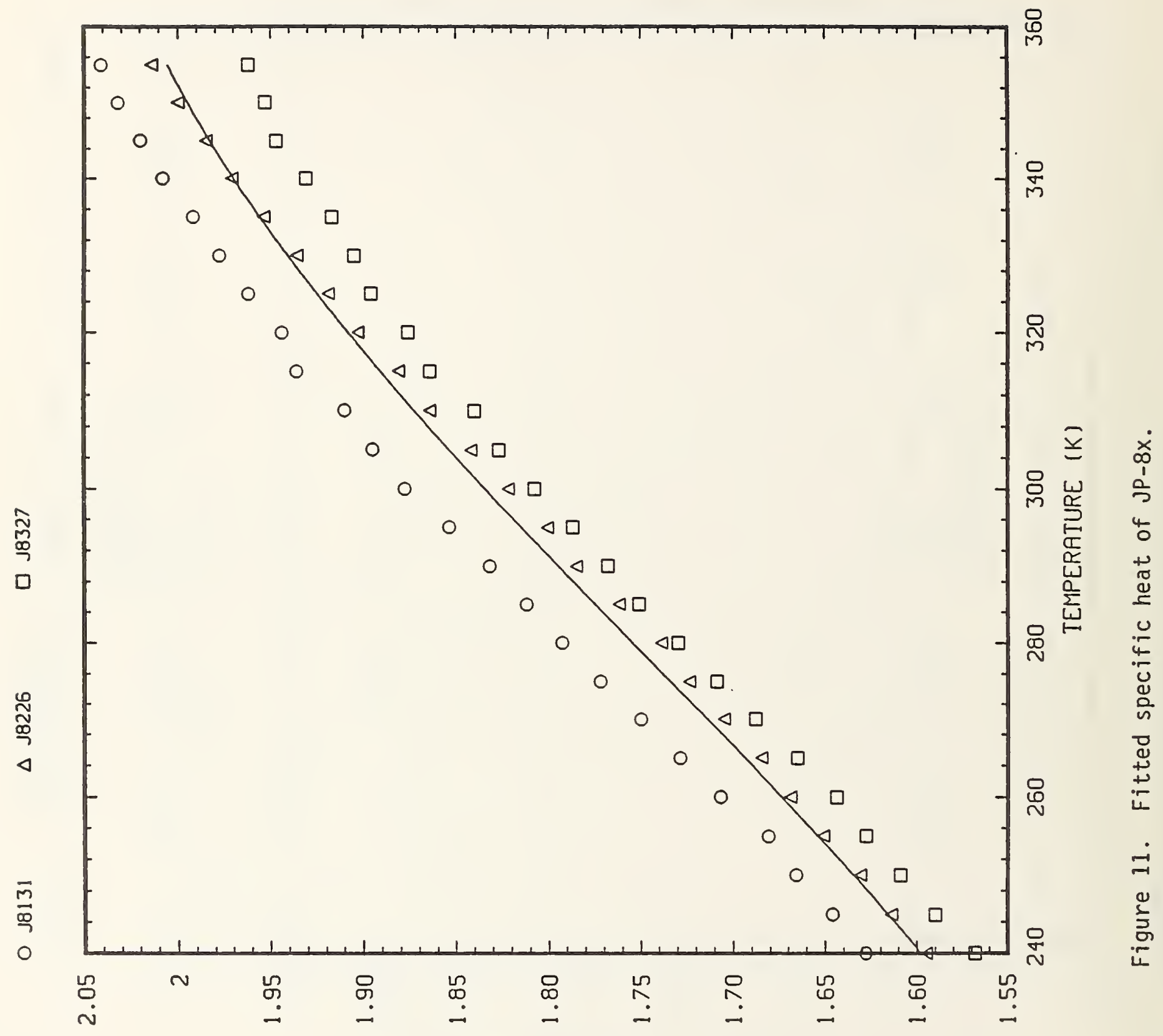

$((x \cdot 9) / \Gamma)$ IHJH JIJIJJdS 


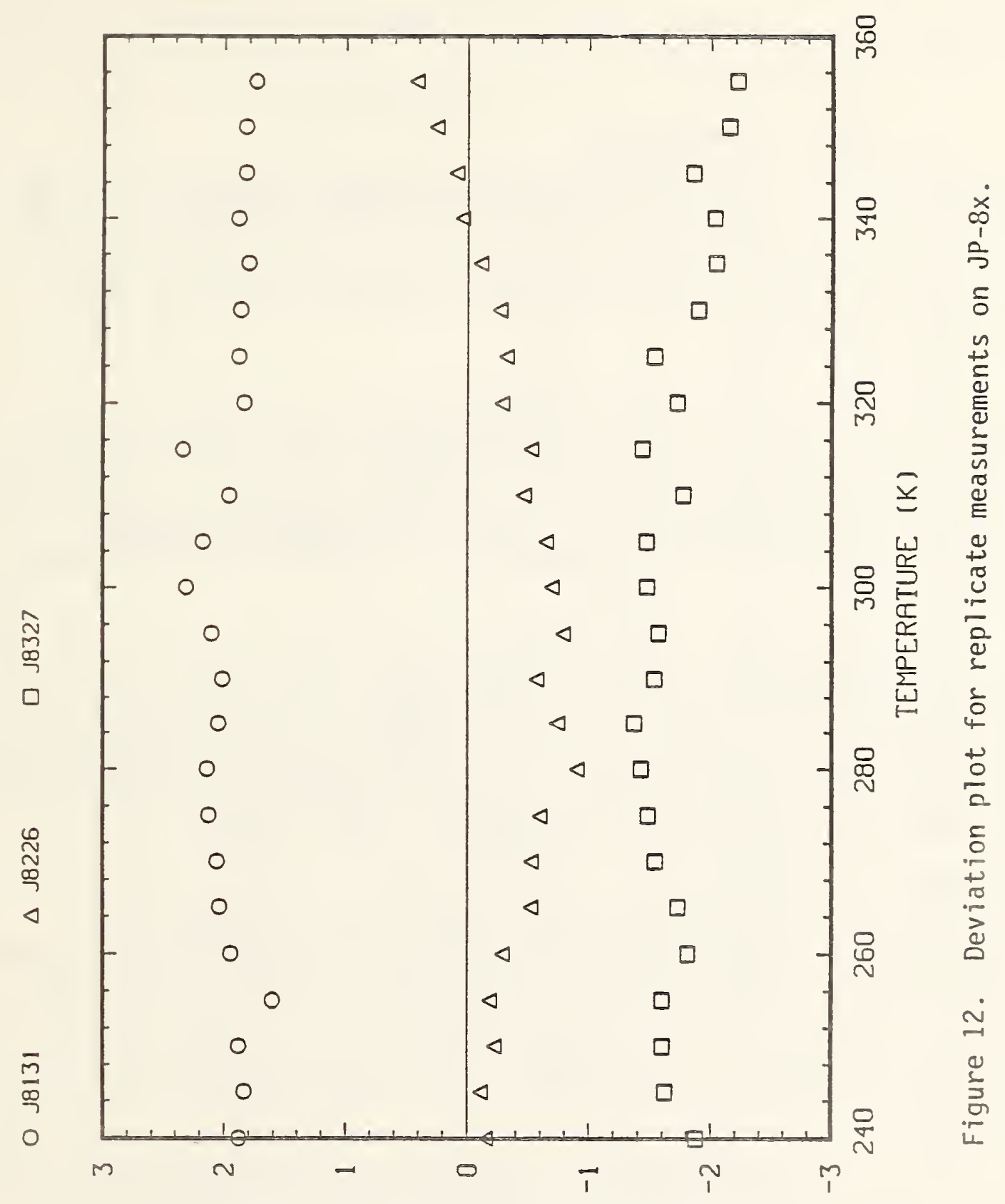

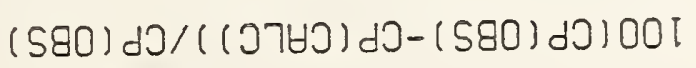


recommended that in the future, precise determination of specimen and cell volumes be made.

\section{APPROACH - ENTHALPY OF VAPORIZATION}

The Calvet calorimeter used was a Setaram combination TG/DSC 111, located at ASTRA Scientific, Inc., San Jose, CA. ${ }^{1}$ The variety of configurations of this equipment allowed for five different modes of measurement. In the time available for this study, only one of these modes was pursued in detail: an isothermal technique that used the balance capability of the equipment in addition to the calorimeter.

The method was devised and tested using pure materials in order to provide an estimate of its accuracy and precision. Reagent grade cyclohexane and cis-decalin, with normal boiling points of $371.58 \mathrm{~K}$ and $468.9 \mathrm{~K}$ respectively, were used for the experiments in which the method was devised. The accuracy and precision of the method were evaluated with the heptane reference material used in the heat capacity studies. The technique was then applied to the fuels.

For the vaporization studies with the calorimeter-balance assembly, the heating unit was maintained in vertical orientation. The sample cups, which were located outside of (above) the heater-detector zone for loading, were suspended from the balance beam. After introduction of the sample, the unit was lowered to introduce the sample to the heated zone. A short period of time was required for the fluctuations, caused by the motion of the system and the temperature equilibration of the sample cells, to cease.

A description of the experimental procedure follows. The calorimeter was equilibrated at the desired temperature; a flow of dry nitrogen was maintained through the measuring system. The liquid to be tested was placed in both the reference and the sample cells of the calorimeter, which were then located outside the heated zone of the calorimeter. The purpose of this technique was to prevent the vaporization signal from beginning until the system had recovered from the disturbance associated with sample pans being lowered into the heated zone and equilibrating. During this time, the sample was evaporating from both cells at the same rate and the signal, once it had recovered from the initial disturbance, was flat. When all the material had evaporated from the reference cell, the differential measuring system detected the vaporization enthalpy and responded. When the sample had evaporated completely, the signal returned to baseline. Figure 13 illustrates the signals obtained from both the calorimeter and balance. Because of the detection of the mass change associated with the sample cell, it was possible to determine the enthalpy of vaporization per gram of sample vaporized. This method can be applied both at the normal boiling point and at temperatures removed from it.

The tasks outlined in the original proposal called for determination of the heat of vaporization at specific temperatures, rather than only at the normal boiling point. Accordingly, measurements were made at a series of temperatures. To allow for comparison with literature data, measurements 
MASS (mg)

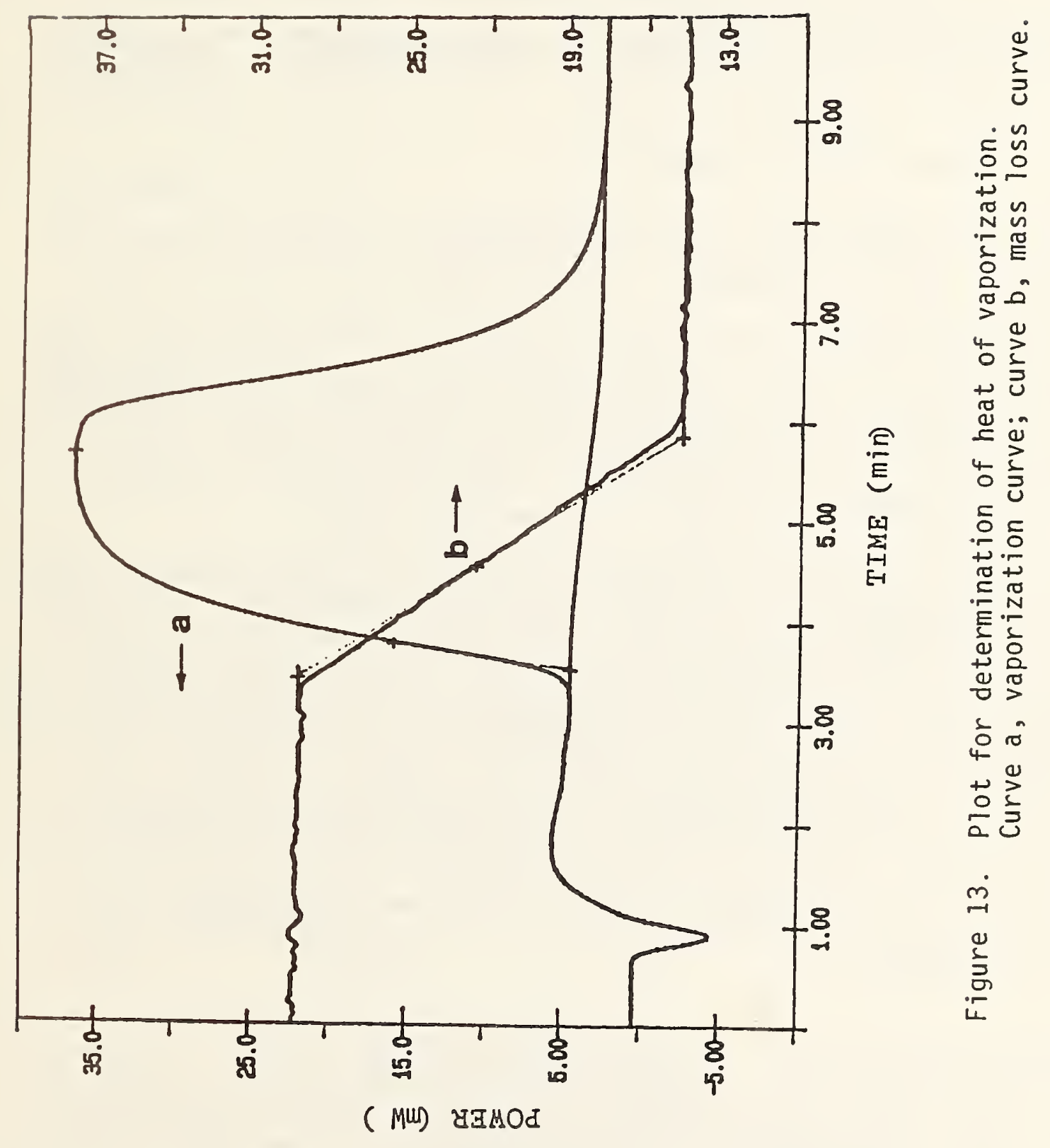


were made also at the boiling points of cyclohexane, cis-decalin, and heptane; heats of vaporization as a function of temperature are not readily available for organic liquids. For comparison with literature data, the data near the normal boiling point have been converted to a molar basis.

Following the development of suitable measuring procedures, the technique was applied to the jet fuels.

\section{RESULTS - ENTHALPY OF VAPORIZATION}

The results of measurements on pure materials by the method outlined above are shown in table 3. Comparison with literature data is made in table 4.

The initial vaporization measurements on the fuels were made on JP-7, since it was the best characterized of the materials. Three $\mu \mathrm{L}$ were used in the sample cell and $1 \mu \mathrm{L}$ in the reference cell. Despite the use of these small amounts of material, the desired flat initial region was almost nonexistent and vaporization from the sample cell was not completed after 75 minutes. A second trial with a $7: 4 \mu \mathrm{L}$ distribution, used to try to get a suitable initial flat portion of the curve, also was unsuccessful.

It was decided to continue measurements on JP-4, which has the highest vapor pressure, thus presumably the lowest vaporization temperature, of the three fuels. Measurements at temperatures lower than $450 \mathrm{~K}$ were not successful. Even at $450 \mathrm{~K}$, a flat region could not be definitively established because of the vaporization of the very light components. GC/MS analysis at NBS-Boulder showed this fuel to have a great many components that boil below or near 373 $\mathrm{K}$. Attempts to measure the disturbance incurred in the system as the pans were lowered into the heated zone, for use as a blank correction, were inconclusive. Since the fuels did not arrive until the last day of work at ASTRA, time for experimentation was very limited. It is very possible that an average blank correction could be determined and allow measurements of the early vaporization. As the final masses determined indicated that some residue remained in the system, it is surmised that some waxy materials never vaporized at $450 \mathrm{~K}$.

Two values were obtained for JP-4 and JP-8x. JP-4 showed a heat of vaporization of $347 \mathrm{~J} \cdot \mathrm{g}^{-1}$; for $\mathrm{JP}-8 \mathrm{x}$, the value was $364 \mathrm{~J} \cdot \mathrm{g}^{-1}$. The value for JP- 4 does not include heat effects associated with the very early vaporization. For a broad spectrum fuel like JP-4, it would be necessary either to make measurements at various temperatures and sum them to get an estimate of the cumulative heat of vaporization or to use a pressure cell that would prevent vaporization until the system had equilibrated. 
Table 3 .

Enthalpy of vaporization for pure materials

\begin{tabular}{|c|c|c|c|c|}
\hline \multirow{2}{*}{$\begin{array}{l}\text { Substance } \& \\
\text { proportions } \\
\mu \mathrm{L} \text { sam:ref }\end{array}$} & \multicolumn{2}{|c|}{ Temperature (K) } & \multirow{2}{*}{$\begin{array}{l}\text { Number of } \\
\text { determinations }\end{array}$} & \multirow{2}{*}{$\begin{array}{l}\text { Enthalpy } \\
\mathrm{J} \cdot \mathrm{g}^{-1}\end{array}$} \\
\hline & Nomina1 & Actual & & \\
\hline Cyclohexane & & & & \\
\hline $24: 6.2$ & 323 & 323.3 & 2 & $381.7 \pm 0.9$ \\
\hline $40: 20$ & 350 & 348.9 & 2 & $353.8 \pm 0.8$ \\
\hline Cis-decalin & & & & \\
\hline $40: 20$ & 470 & 463.4 & 3 & $288.7 \pm 1.6$ \\
\hline Heptane & & & & \\
\hline $3: 1$ & 300 & 302.6 & 5 & $381.0 \pm 1.4$ \\
\hline $22: 10$ & 350 & 344.5 & 5 & $349.4 \pm 1.1$ \\
\hline $50: 30$ & 371 & 363.2 & 5 & $328.9 \pm 2.9$ \\
\hline
\end{tabular}

Table 4.

Comparison with literature data - enthalpy of vaporization

\begin{tabular}{|c|c|c|c|}
\hline \multicolumn{2}{|c|}{ Literature } & \multicolumn{2}{|c|}{ Experimental } \\
\hline$\underset{\mathrm{K}}{\operatorname{Boiling}}$ point & $\begin{array}{l}\text { Enthalphy } \\
\mathrm{kJ} \cdot \mathrm{mol}^{-1}\end{array}$ & $\begin{array}{c}\text { Temperature } \\
\mathrm{K}\end{array}$ & $\begin{array}{l}\text { Enthalpy } \\
\mathrm{kJ} \cdot \mathrm{mol}-1\end{array}$ \\
\hline \multicolumn{4}{|c|}{ Cyclohexane [12] } \\
\hline 353.88 & 30.08 & 348.87 & 29.77 \\
\hline \multicolumn{4}{|c|}{ Cis-decalin [13] } \\
\hline 468.90 & 39.33 & 463.45 & 39.91 \\
\hline \multicolumn{4}{|c|}{ Heptane [12] } \\
\hline 371.58 & 31.69 & 363.18 & 32.96 \\
\hline
\end{tabular}


The proportions of sample to be placed in the reference and sample cells varied with the properties of the liquid tested. The amount necessary had to be determined empirically for each liquid at each temperature.

JP-4, in particular, has some very low boiling components despite a majority concentration of high boiling components. Even at $450 \mathrm{~K}$, the higher boiling materials did not vaporize at a reasonable rate; the low boiling materials could not be contained at this temperature without application of pressure. Several possibilities exist for overcoming this problem but the time and funds available did not permit their application. Further discussion of those methods will be pursued with Pratt and Whitney at a later time.

In the early experiments, the calorimeter signal appeared to be swamped if measurements were repeated at frequent intervals. This was believed to result from residual vapors in the detection zone. A flow of dry nitrogen, maintained through the detection zone, solved this problem completely.

\section{ACKNOWLEDGEMENTS}

We thank M. Ducros of the Ecole Nationale Superieure des Techniques Avancees, Palaiseau, France for helpful suggestions with regard to the heat of vaporization measurements.

The work reported here was conducted under subcontract to the Materials Engineering Laboratory of Pratt and Whitney. The work was sponsored by the Fuels Branch of the Aeropropulsion Laboratory, Air Force Wright Aeronautical Laboratories, under Contract No. F33615-85-C-2500. 
[1] Partington, J.R. An Advanced Treatise on Physical Chemistry New York: Longmans ; 1951.

[2] Farritor, R. E. ; Tao, L. C. Thermochim. Acta 1: 297-304; 1970.

(3) Mita, I.; Imai, I.; Kambe, H. Thermochim. Acta 2: 337-344; 1971.

[4] Hsu, S.M.; Cummings, A. L.; Clark, D. B. Base Oils for Automotive Lubricants, SP-526: 127-139. Society for Automotive Engineers, Inc. 1982.

[5] Barone, G.; Della Gatta, G.; Elia, V. J. Therm. Ana1. 29: 763-772; 1984.

[6] Brostow, W.; Iniguiz, J. C.; Shmorhun, M. A. Materials Chemistry and Physics 12: 557-569; 1985.

[7] Callanan, J. E.; Sullivan, S. A.; Rev. Sci. Instr. 56: 2584-2592; 1986.

[8] Ditmars, D. A.; Ishihara, S.; Chang, S. S.; Bernstein, G.;West, E. D. Enthalpy and heat-capacity standard reference material: synthetic sapphire $\left(\alpha-\mathrm{Al}_{2} \mathrm{O}_{3}\right)$ from $10-2250 \mathrm{~K}$. Journal of Research (N. B. S.) 87: $159-163$; 1982 .

[9] Ginnings, D. C.; Furukawa, G. T. Heat capacity standards for the range 14-1200 K. J. Am. Chem. Soc. 75: 522-527; 1953.

[10] Office of Standard Reference Materials, National Bureau of Standards, Gaithersburg, MD. 20899

[11] Office of Reference Materials, National Physical Laboratory, Teddington, Middlesex TW11 OLW, UK.

[12] Stul1, D. R.; Westrum, E. F. Jr.; Sinke, G. C. The Chemical Thermodynamics of Organic Compounds. New York: Wiley; 1969

[13] Reid, R. C.; Prausnitz, J. M.; Sherwood, T. K. The Properties of Gases and Liquids, 3rd ed. New York: McGraw-Hi11; 1977. 
S. OEPT. OF COMM

BIBLIOGRAPHIC DATA

SHEET (See instructions)

4. TITLE AND SUBTITLE
1. PUBLICATION OR REPORT NO.

NBSIR 88-3093
2. Performing Organ. Report No.

3. Publication Date

DEVELOPMENT OF STANDARD MEASUREMENT TECHNIQUES AND STANDARD REFERENCE MATERIALS FOR HEAT CAPACITY AND HEAT OF VAPORIZATION OF JET FUELS

5. $A \cup T H O R(S)$

Jane E. Callanan

6. PERFORMING ORGANIZATION (If joint or other than NBS, see instructions)

NATIONAL BUREAU OF STANDARDS

DEPARTMENT OF COMMERCE

WASHINGTON, D.C. 20234

August 1988

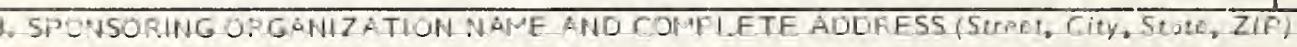

Aero Propulsion Laboratory

Air Force Wright Aeronautical Laboratories

Wright-Patterson AFB, Ohio 45433-6563

10. SUPPLEMENTARY NOTES

Document describes a computer program; SF-185, FIPS Software Summary, is attached.

11. ABSTRACT (A 200-word or less factual summary of most significant information. If document includes a significant bibliography or literature survey. mention it here)

Procedures developed in the NBS-Boulder Laboratory for heat capacity measurements of solids have been adapted successfully for the determination of liquid heat capacities. Heptane was used as a standard in the measurement of the heat capacity of three jet fuels, JP-4, JP-7, and JP-8x, from 220 to $360 \mathrm{~K}$. Transitions were observed in these fuels as follows (fuel, temperature): JP-4, $320 \mathrm{~K}$; JP-7, 220-230 K; JP-8x, 220-240 K. Combined thermogravimetric and scanning calorimetric techniques were used successfully to measure heats of vaporization of cyclohexane, cis-decalin, and heptane. The precision of these measurements was better than 0.9 percent; agreement with literature values was satisfactory in view of small differences between the measuring temperature and the literature values for the boiling points.

12. KEY WORDS (Six to twelve entries; alphabetical order: capitalize only proper names; and separate key words by semicolons) differential scanning calorimetry; heat capacity; heat of vaporization; jet fuels; organic liquids; thermogravimetry.

13. AVAILABILITY

[x] Unlimited

For Official Distribution. Do Not Release to NTIS

$\square$ Order From Superintendent of Documents, U.S. Government Printing Office, Washington, D.C. 20402.

$\mathrm{X}$ Order From National Technical Information Service (NTIS), Springfield, VA. 2216I

14. NO. OF

PRINTED PAGES 36

15. Price 


